\title{
PENGARUH MODEL PEMBELAJARAN BERBASIS MASALAH TERHADAP LITERASI SAINS PESERTA DIDIK
}

\section{THE INFLUENCE OF PROBLEM BASED LEARNING MODEL FOR SCIENCE LITERATION OF STUDENTS}

\author{
Lena Marlina*, Muntari, dan Baiq Fara Dwirani Sofia \\ Program Studi Pendidikan Kimia FKIP Universitas Mataram, Mataram, Indonesia \\ *Email: lenamarlina1705@gmail.com
}

Diterima: 17 Agustus 2020. Disetujui: 8 Desember 2020. Dipublikasikan: 9 Januari 2021

\begin{abstract}
Abstrak: Penelitian ini bertujuan untuk mengetahui ada atau tidaknya pengaruh model pembelajaran berbasis masalah terhadap literasi sains peserta didik kelas X pada materi pokok larutan elektrolit dan non-elektrolit. Metode yang digunakan adalah metode quasi experiment dengan rancangan penelitian post-test only control group design. Populasi penelitian adalah seluruh peserta didik kelas X MIA MAN 2 Model Mataram. Pengambilan sampel dilakukan dengan teknik cluster random sampling. Sampel dalam penelitian ini adalah peserta didik kelas X MIA 1 and X MIA 4 MAN 2 Model Mataram. Hasil penelitian menunjukkan bahwa literasi sains peserta didik pada materi larutan elektrolit dan non-elektrolit dengan menggunakan model pembelajaran berbasis masalah menghasilkan nilai rata-rata posttest 76.17 . Sedangkan pada kelas yang menggunakan metode konvensional menghasilkan nilai rata-rata posttest 66.75 . Pengujian hipotesis dalam penelitian ini menggunakan rumus uji-t sparated varians. Hasil uji-t pada taraf signifikan 5\% diperoleh nilai $t_{\text {hitung }}(4.14) \geq t_{\text {tabel }}$ (1.671), yang berarti $\mathrm{H}_{0}$ ditolak dan $\mathrm{H}_{\mathrm{a}}$ diterima. Sehingga dapat disimpulkan bahwa penerapan model pembelajaran berbasis masalah (PBM) memberikan pengaruh yang lebih baik dan signifikan terhadap literasi sains peserta didik kelas X pada materi pokok larutan elektrolit dan non-elektrolit dibandingkan model pembelajaran konvensional.
\end{abstract}

Kata kunci: Pembelajaran Berbasis Masalah, Literasi Sains, Elektrolit dan Non-Elektrolit

\begin{abstract}
This research aims to determine the presence or absence of influence of problem-based learning model on the literacy science of class X students on the subject matter of electrolyte and non-electrolyte.The method used is the method of quasi experiment with research design post-test only control group design. The study population was all students of class X MIA MAN 2 Model Mataram. The sampling is using done with the technique cluster random sampling. The sample of the research are the students of grade X MIA 1 and X MIA 4 MAN 2 Mataram Model. The results of the study shows that the ability of students Science literacy on the material of electrolyte and non-electrolyte using the problem-based learning model resulted the average score of posttest 76.17. While in the grade using the method of conventional learning model resulted the average score of posttest 66.75. The hypothesis test in this research using t-test sparated varians. T-test results at a significant level of $5 \%$ obtained $t_{\text {count }}(4.14) \geq t_{\text {table }}\left(1.671\right.$,) which means that $\mathrm{H}_{0}$ is rejected and $\mathrm{H}_{\mathrm{a}}$ is accepted. So it can be concluded that application of problem based learning model had a better influence and significant on the literacy science of class X students on the subject matter of electrolyte and non-electrolyte solutions compared to conventional learning model.
\end{abstract}

Keywords: Problem-Based Learning, Science Literacy, Electrolyte and Non-Electrolyte

\section{PENDAHULUAN}

Pembelajaran kimia merupakan salah satu bagian dari pembelajaran sains, sehingga pembelajaran kimia juga bertanggung jawab terhadap pencapaian literasi kimia peserta didik. Menurut Hurt dalam Toharudin [1], science literacy berarti tindakan memahami sains dan mengaplikasikannya bagi kehidupan masyarakat. Literasi sains termasuk dalam keterampilan untuk hidup karena peserta didik mampu mengaplikasikan pengetahuannya dalam menghadapi situasi nyata.

Terkait dengan kemampuan literasi sains peserta didik Indonesia, studi penilaian yang dilakukan oleh PISA (Programme for International Students Asassement) mengungkapkan bahwa rata-rata kemampuan literasi sains peserta didik Indonesia sejak tahun 2000 sampai 2012 selalu mengalami penurunan [1]. Sedangkan pada tahun 2016 peringkat Indonesia naik pada posisi 62 dari 70 peserta yang termasuk kedalam survei. Temuan tersebut menunjukkan walaupun kemampuan literasi sains mengalami peningkatan pada tahun 2016, tetapi dibandingkan dengan negara lain, kemampuan literasi sains peserta didik di Indonesia masih dikatakan termasuk dalam kategori rendah [2]. 
Rendahnya literasi sains peserta didik menurut Fathurohman ,dkk [3] dipengaruhi oleh banyak hal, salah satu di antaranya adalah pemilihan model pembelajaran oleh guru. Pendapat ini didukung pula oleh Taufiq, dkk [4], yang menyatakan bahwa salah satu faktor yang secara langsung bersinggungan dengan kegiatan pembelajaran dan mempengaruhi rendahnya kemampuan literasi peserta didik Indonesia adalah pemilihan model pengajaran oleh guru.

Pemilihan model pembelajaran yang tepat merupakan hal penting yang harus diterapkan oleh guru agar memperoleh hasil yang optimal. Salah satu model pembelajaran yang dapat digunakan adalah Model Pembelajaran Berbasis Masalah (PBM). Model PBM merupakan salah satu model pembelajaran yang membangun literasi sains peserta didik, dimana peserta didik menjadi pusat dari pembelajaran. Kekuatan PBM berada dan dapat ditemukan dalam proses pembelajarannya melalui pendekatan langsung oleh peserta didik. Dimana fakta dan ide-ide ilmiah diajarkan secara langsung, tetapi masih terintegrasi di dalam proses ilmiah [1].

Beberapa penelitian telah dilakukan untuk melihat pengaruh penerapan model PBM terhadap literasi sains peserta didik. Menurut penelitian yang dilakukan oleh Putri, dkk [5], menunjukan nilai rata-rata kemampuan literasi sains peserta didik di kelas eksperimen (48.47) lebih tinggi dibandingkan kelas kontrol (26.95). Penelitian yang relevan juga sudah dilakukan oleh Giriyanti, dkk [6], yang menyatakan bahwa terdapat pengaruh model pembelajaran berbasis masalah terhadap kemampuan literasi sains peserta didik dengan perolehan hasil kemampuan literasi sains peserta didik kelas eksperimen pada kategori sedang (0.56), sedangkan pada kelas kontrol berada pada kategori rendah (0.27).

Ilmu kimia merupakan salah satu mata pelajaran yang dilaksanakan dalam pembelajaran di SMA. Menurut Pandley dalam Suyanti [7], banyaknya konsep kimia yang bersifat abstrak yang harus diserap dalam waktu relatif terbatas menjadikan ilmu kimia sebagai salah satu mata pelajaran sulit bagi peserta didik sehingga banyak yang gagal dalam belajar kimia. Salah satu materi pokok yang ada dalam mata pembelajaran kimia adalah larutan elektrolit dan non-elektrolit. Menurut Astuti [8], materi larutan elektrolit dan non-elektrolit merupakan salah satu konsep kimia yang bersifat abstrak (submikroskopis). Untuk itu diperlukan suatu metode pembelajaran yang tepat agar materi larutan elektrolit dan non-elektrolit dapat disampaikan dengan baik.

Berdasarkan hasil observasi dan wawancara dengan guru mata pelajaran kimia di MAN 2 Model Mataram, diperoleh informasi bahwa guru sering menerapkan model pembelajaran konvensional yang didominasi dengan metode ceramah. Proses pembelajaran tersebut berpusat pada guru (teacher sentries) yang akan menyebabkan peserta didik menjadi pasif dan partisipasi dalam proses pembelajaran menjadi relatif rendah. Sehingga sangat dibutuhkan strategi pembelajaran yang menyenangkan, melibatkan peserta didik, meningkatkan aktivitas, dan kerjasama, serta rasa tanggung jawab peserta didik dalam konteks pengajaran.

Strategi yang dimaksudkan sebagai daya upaya guru dalam menciptakan suatu sistem lingkungan yang memungkinkan terjadinya proses mengajar agar tujuan pembelajaran yang telah dirumuskan dapat tercapai dan berhasil [7]. Salah satu model pembelajaran yang dapat digunakan adalah model pembelajaran berbasis masalah (PBM). Model pembelajaran berbasis masalah (PBM) memiliki ciri khas yaitu selalu dimulai dengan masalah dan berpusat pada masalah. Model PBM dapat digunakan di dalam kelompokkelompok kecil dan harus mengidentifikasi apa yang mereka ketahui serta apa yang mereka tidak ketahui dan harus belajar untuk memecahkan masalah, dimana peran utama dari guru sebenarnya hanya untuk memudahkan proses belajar, bukan untuk menyediakan jawaban secara langsung [9].

Berdasarkan latar belakang di atas peneliti tertarik untuk melakukan penelitian dengan judul "Pengaruh Model Pembelajaran Berbasis Masalah terhadap Literasi Sains Peserta Didik Kelas X pada Materi Pokok Larutan Elektrolit dan NonElektrolit",

\section{METODE PENELITIAN}

Penelitian ini dimulai dengan tahap perencanaan penelitian dari bulan Agustus 2019 dan pelaksanaan penelitian pada bulan Februari Maret 2020 bertempat di MAN 2 Model Mataram pada peserta didik kelas X MIA tahun ajaran 2019/2020.

Jenis penelitian yang digunakan dalam penelitian ini adalah eksperimen semu (quasi eksperimental) menggunakan post-test only control group design. Teknik pengambilan sampel (sampling) yang digunakandalam penelitian ini yaitu teknik cluster random sampling. Cluster random sampling merupakan teknik pengambilan sampel kelas secara acak dari kelas-kelas yang sudah ada sebagai suatu populasi. Teknik ini merupakan teknik kombinasi dari cluster sampling dan random sampling [10]. Sehingga terpilih dua kelas sebagai kelas eksperimen dan kelas kontrol. Kelas eksperimen diberi perlakuan berupa pembelajaran dengan model pembelajaran berbasis masalah sedangkan pada kelas kontrol menggunakan model pembelajaran konvensional (ceramah). 
Variabel yang diamati dalam penelitian ini berupa variabel bebas dan variabel terikat. Variabel bebas merupakan variabel yang mempengaruhi atau yang menjadi sebab perubahan pada variabel terikat [10]. Variabel bebas yang dimaksud adalah proses pembelajaran menggunakan model pembelajaran berbasis masalah. Sedangkan variabel terikat merupakan variabel yang dipengaruhi atau menjadi akibat adanya variabel bebas. Variabel terikat dalam penelitian ini adalah literasi sains peserta didik.

Populasi dalam penelitian ini yaitu seluruh peserta didik kelas X MIA MAN 2 Model Mataram yang berjumlah 178 orang yang tersebar dalam 5 kelas. Penentuan kelas eksperimen dan kelas kontrol dalam penelitian ini dilakukan secara acak dengan menggunakan undian sederhana. Dari hasil pengundian tersebut ditetapkan bahwa kelas $\mathrm{X}$ MIA 4 sebagai kelas eksperimen dan Kelas X MIA 1 sebagai kelas kontrol. . Kedua kelas yang terpilih sebagai sampel setelah dilakukan uji homogenitas awal diperoleh hasil perhitungan $F_{\text {hitung }}(1,18)<F_{\text {tabel }}(1,78)$ pada taraf signifikan $5 \%$, yang artinya varians kedua sampel homogen.

Penelitian ini menggunakan instrumen berupa tes literasi sains dalam bentuk soal uraian. Instrumen yang telah disusun terlebih dahulu diuji validitas dan reliabilitasnya. Uji validitas instrumen pada penelitian ini ada 2 yaitu pengujian validitas isi dan validitas butir soal. Validitas isi menggunakan rumus Aiken's V sedangkan untuk validitas butir soal menggunakan rumus korelasi product momen. Berdasarkan hasil perhitungan validitas isi, instrumen yang disusun layak digunakan sebagai alat pengumpul data. Sedangkan untuk pengujian validitas butir soal diperoleh hasil analisis yang menunjukkan bahwa terdapat 8 soal yang valid dari 10 soal yang telah disusun, namun 8 soal tersebut sudah mewakili setiap indikator yang ingin diuji..

Uji hipotesis dihitung menggunakan data posttest untuk mengetahui apakah ada perbedaan antara kedua sampel setelah diberikan perlakuan. Berdasarkan uji normalitas dan homogenitas, jika data yang diperoleh memenuhi uji asumsi yakni data terdistribusi normal dan homogen, maka uji hipotesis digunakan statistik uji-t [10]. Berdasarkan uji normalitas dan homogenitas yang telah dilakukan, diperoleh data bahwa hasil penelitian memenuhi uji asumsi yakni data terdistribusi normal dan homogen, sehingga uji hipotesis digunakan statistik uji-t sparated varians.

\section{HASIL DAN PEMBAHASAN}

Tujuan dilakukannya penelitian ini yaitu untuk mengetahui ada atau tidaknya pengaruh model pembelajaran berbasis masalah terhadap literasi sains peserta didik pada materi pokok larutan elektrolit dan nonelektroit. Model pembelajaran yang diterapkan di kelas eksperimen yaitu model Pembelajaran Berbasis Masalah (PBM), sedangkan pada kelas kontrol menggunakan model pembelajaran konvensional (ceramah) dengan alokasi waktu masing-masing 3 kali pertemuan ( 9 x 45 menit).

Keterlaksanaan dan kesesuaian selama proses pembelajaran pada kelas kontrol dan kelas eksperimen diukur dengan lembar observasi aktivitas guru dan lembar observasi aktivitas peserta didik. Persentase hasil observasi aktivitas guru dapat dilihat pada Grafik 1 berikut:

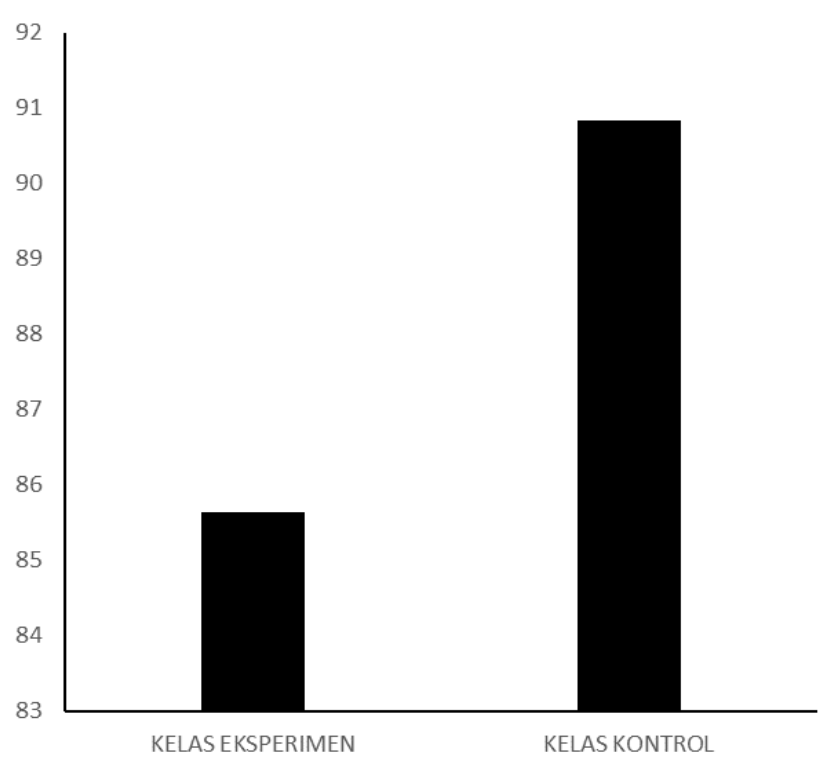

Gambar 1. Persentase Hasil Observasi Aktivitas Guru

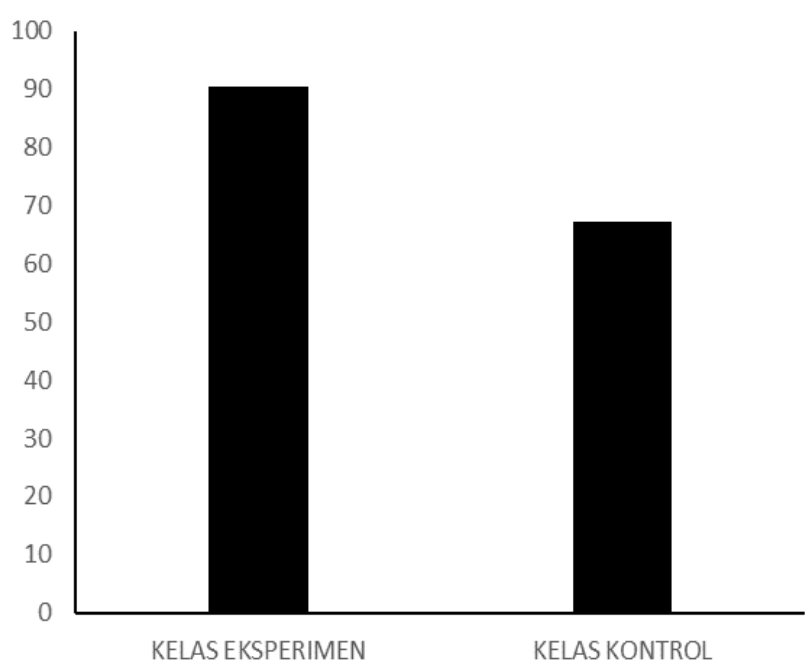

Gambar 2. Persentase Aktivitas Peserta Didik

Pada grafik 1 di atas dapat dilihat bahwa keaktifan guru pada kelas eksperimen dan kelas kontrol tinggi. Persentase keaktifan guru kelas eksperimen dan kelas kontrol berdasarkan lembar 
observasi masing-masing adalah $85.63 \%$ dan $90.83 \%$. Hal tersebut menunjukan bahwa pada proses pembelajaran guru sudah sesuai dengan sintak setiap model pembelajaran yang diterapkan. Sedangkan grafik nilai rata-rata Persentase aktivitas peserta didik pada kelas eksperimen dan kontrol dapat dilihat pada Grafik 2.

Pada Grafik 2 tersebut dapat dilihat bahwa hasil observasi keaktifan peserta didik pada kelas eksperimen lebih tinggi dibandingkan dengan kelas kontrol. Persentase keaktifan peserta didik kelas eksperimen dan kelas kontrol berdasarkan lembar observasi masing-masing adalah $90.38 \%$ dan $67.31 \%$. Adapun aspek-aspek yang dinilai dalam lembar observasi aktivitas peserta didik yakni antusias peserta didik dalam mengikuti pembelajaran, interaksi peserta didik dengan guru, interaksi peserta didik dengan peserta didik dan partisipasi peserta didik dalam menyimpulkan pembelajaran.

Dari data hasil observasi aktivitas guru dan peserta didik tersebut termasuk ke dalam kategori baik sehingga menunjukkan bahwa proses pembelajaran terlaksana sesuai dengan langkahlangkah yang direncanakan peneliti. Tingginya aktifitas peserta didik pada kelas eksperimen dikarenakan kelas eksperimen menerapkan model pembelajaran berbasis masalah, dimana guru sebagai motivator dan pemberi arah sementara peserta didik yang berperan aktif dalam proses pembelajaran. Peran guru sebagai motivator adalah memotivasi dan mendorong peserta didik agar selalu aktif meningkatkan kemampuan berpikir, memahami masalah serta dapat mempertanggungjawabkan hasil diskusi yang dilakukan.

Keaktifan peserta didik dalam proses pembelajaran pada kelas eksperimen dapat dilihat dari kegiatan diskusi dengan teman kelompok, mengemukakan pendapat serta aktivitas bertanya. Di kelas eksperimen peserta didik yang aktif bertanya dan mengemukakan pendapatnya lebih banyak dibandingkan kelas kontrol. Hal ini menandakan bahwa minat belajar kelas eksperimen juga lebih tinggi karena peserta didik yang benar-benar berminat pada suatu pelajaran akan selalu bertanya apabila ada yang belum dipahami. Pernyataan tersebut dikemukan oleh Astuti [8], bahwa tinggi rendahnya minat peserta didik terhadap mata pelajaran yang diajarkan berkaitan erat dengan rasa ingin tahu atau kebutuhan akan informasi yang salah satunya dengan mengajukan pertanyaan.

Data hasil literasi sains peserta didik dalam penelitian ini diperoleh melalui posttest pada materi larutan elektrolit dan non-elektrolit. Posttest dilaksanakan pada pertemuan terakhir setelah selesai materi dengan alokasi waktu 120 menit. Posttest diikuti oleh kelas X MIA 4 (kelas eksperimen) dan kelas X MIA 1 (kelas kontrol) yang masing-masing berjumlah 36 orang. Jawaban peserta didik dinilai berdasarkan rubrik penilaian literasi sains peserta didik yang mencakup ketiga dimensi literasi sains.

Dimensi literasi sains yang diukur adalah: 1) Konten (Mengetahui dam memahami sejumlah konsep tentang larutan elektrolit untuk memahami fenomena alam tertentu dan perubahan-perubahan yang terjadi akibat kegiatan manuasia), 2) Proses (Mengkaji kemampuan peserta didik untuk menggunakan pengetahuan dan pemahaman sains tentang larutan elektrolit dan nonelektrlit), 3) Konteks (Menjelaskan fenomena alam dan fenomena hasil kegiatan manusia dengan menggunakan konsep larutan elektrolit dan nonelektrolit).

Grafik nilai rata-rata posttest untuk setiap dimensi literasi sains peserta didik pada kelas eksperimen dan kelas kontrol disajikan pada gambar 3 .

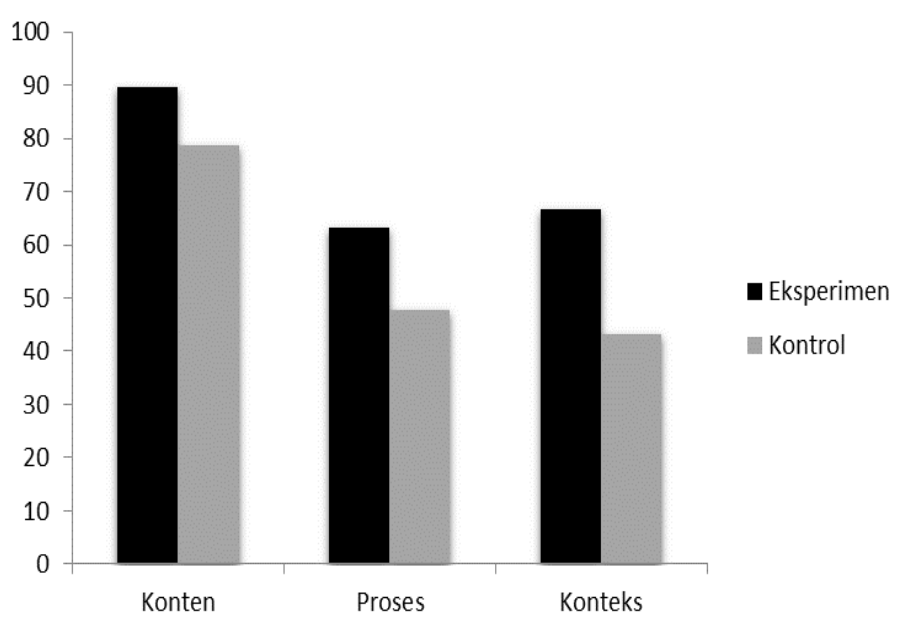

Gambar 3. Perbandingan nilai rata-rata posttest setiap dimensi kelas eksperimen dan kelas kontrol

Berdasarkan grafik di atas, terlihat bahwa nilai rata-rata posttest pada setiap dimensi literasi sains peserta didik yang terdiri dari dimensi konten, proses, dan konteks pada kelas eksperimen lebih tinggi daripada kelas kontrol sehingga dapat disimpulkan bahwa literasi sains peserta didik pada kelas eksperimen lebih tinggi dari pada literasi sains peserta didik pada kelas kontrol.

Untuk mengetahui adanya pengaruh model pembelajaran berbasis masalah terhadap kemampuan literasi sains maka dilakukan uji hipotesis terhadap nilai posttest. Sebelum melakukan uji hipotesis, nilai posttest diuji normalitas dan homogenitas terlebih dahulu. Hal ini dilakukan untuk mengetahui jenis uji hipotesis mana yang akan digunakan.

Berdasarkan uji normalitas dan homogenitas yang telah dilakukan, diperoleh 
bahwa data hasil penelitian terdistribusi normal dan bersifat homogen, sehingga uji hipotesis yang digunakan adalah uji-t. Hasil perhitungan uji $\mathrm{t}$ diperoleh nilai $t_{\text {hitung }}$ sebesar 4.14. Sedangkan pada taraf signifikan $5 \%$ dan $\mathrm{dk} 70$ diperoleh nilai $\mathrm{t}_{\text {tabel }}$ sebesar 1.671 yang menunjukan bahwa nilai thitung lebih besar dari $\mathrm{t}_{\text {tabel }}$ sehingga $\mathrm{H}_{0}$ ditolak dan $\mathrm{H}_{\mathrm{a}}$ diterima. Hal ini menunjukan bahwa penerapan model pembelajaran berbasis masalah (PBM) memberikan pengaruh yang lebih baik terhadap literasi sains peserta didik kelas $\mathrm{X}$ pada materi pokok larutan elektrolit dan non-elektrolit dibandingkan model pembelajaran konvensional.

Model pembelajaran berbasis masalah membuat siswa mengalami serangkaian proses yang mendukung tercapainya indikator kemampuan literasi sains. Proses pembelajaran berlangsung selama 3 pertemuan dengan 5 tahap model pembelajaran berbasis masalah. Tahapantahapan pembelajaran ini berdampak terhadap peningkatan literasi sains peserta didik.

Tahap pertama yaitu tahapan orientasi terhadap pokok bahasan yaitu larutan elektrolit dengan cara menyampaikan apersepsi pembelajaran dan mengorientasi peserta didik pada masalah tentang larutan elektrolit dalam kehidupan sehari-hari. Pada tahap ini cukup membuat peserta didik menjadi antusias dan memiliki semangat untuk memulai proses pembelajaran. Hal ini sesuai dengan pendapat Astuti [8], dalam membuka pembelajaran dengan guru memperlihatkan gambar, cuplikan film atau sesuatu yang unik dapat menarik perhatian peserta didik.

Tahap kedua yaitu mengorganisasikan peserta didik dalam pembelajaran, dimana pada tahap ini peserta didik melakukan eksperimen tentang materi larutan elektrolit dan non-elektrolit. Sedangkan guru hanya mengarahkan dan membimbing peserta didik. Kemudian dilanjutkan dengan tahapan ketiga yakni membimbing pengkajian individu dan kelompok. Pada tahap ini peserta didik melakukan diskusi dalam kelompoknya untuk menyelesaikan soal-soal yang ada pada LKPD dengan memanfaatkan berbagai literatur. Kegiatan diskusi ini mendorong peserta didik untuk berpikir dan memecahkan masalah dalam diskusi kelompok, membuat peserta didik mendalami kembali materi yang akan dipelajari, dan memberikan peserta didik untuk mengemukakan pendapat. Dalam diskusi kelompok peserta didik dapat menemukan sendiri konsep dengan mengerjakan latihan sehingga peserta didik mengetahui makna dari konsepkonsep yang dipelajari dan memperluas pengetahuan. mengajarkan peserta didik untuk saling berinteraksi dengan anggota kelompok sehingga peserta didik mampu bekerjasama dan saling mengemukakan pendapat $[11,13,14]$.
Selanjutnya tahapan keempat yaitu mengembangkan dan menyajikan hasil karya. Pada tahapan ini peserta didik menyiapkan laporan hasil eksperimen berdasarkan literatur yang sudah diperoleh dan mempresentasikan hasilnya ke depan kelas. Pada tahap ini dapat melatih kemampuan peserta didik untuk untuk melakukan komunikasi ilmiah, mengembangkan pengetahuan dan bertanggung jawab dalam pembelajaran yang mereka lakukan [1].

Tahap kelima yaitu menganalisa dan mengevaluasi proses pemecahan masalah. Pada tahap ini guru memberikan kesempatan kepada peserta didik dari kelompok lain untuk memberikan tanggapan terhadap hasil diskusi kelompok penyaji dengan sopan dan memberikan kesempatan kepada kelompok lain yang mempunyai jawaban yang berbeda dari kelompok penyaji untuk mengkomunikasikan hasil diskusi kelompoknya. Peserta didik diberikan kesempatan untuk mengemukan pendapat mereka sesuai dengan pengetahuan yang mereka miliki. Selain itu peserta didik didorong untuk melakukan evaluasi atau menilai kemampuan belajarnya sendiri. Tahapan ini merupakan nilai positif dari pembelajaran berbasis masalah yaitu memberikan kesempatan pada peserta didik untuk mengaplikasikan pengetahuan yang mereka miliki dan mendorong peserta didik melakukan evaluasi sendiri baik terhadap hasil maupun proses belajarnya [1].

Tahapan terakhir yaitu memberikan penguatan materi dengan bersama-sama menyelesaikan permasalahan yang berhubungan dengan materi sehingga peserta didik lebih dapat memahami lagi tentang materi yang sudah dipelajari.

Berdasarkan uraian di atas, model pembelajaran berbasis masalah yang diterapkan dalam proses pembelajaran mengajak peserta didik lebih aktif dalam proses pembelajaran, lebih memberikan kesempatan kepada kelompok untuk saling bekerjasama dalam memahami materi yang telah diberikan, dan saling mengemukakan pendapat, peserta didik terlihat sangat antusias sehingga dapat meningkatkan literasi sains peserta didik. Hal tersebut menunjukkan peserta didik merespon baik kegiatan pembelajaran yang dilakukan. Pendapat ini sejalan dengan penelitian yang dilakukan oleh Giriyanti, dkk [6] yang menyatakan bahwa penerapan model pembelajaran berbasis masalah memperoleh respon sangat baik dari peserta didik yang dapat meningkatkan literasi sains peserta didik dengan kategori peningkatan sedang $(0,56)$.

\section{KESIMPULAN}

Berdasarkan data hasil penelitian menunjukkan bahwa pembelajaran pada kelas 
eksperimen menghasilkan nilai posttest lebih tinggi (76.17) dibandingkan kelas kontrol (66.77). Sehingga dapat disimpulkan bahwa penerapan model pembelajaran berbasis masalah (PBM) memberikan pengaruh yang lebih baik terhadap literasi sains peserta didik kelas X pada materi pokok larutan elektrolit dan non-elektrolit dibandingkan model pembelajaran konvensional.

\section{DAFTAR PUSTAKA}

[1] Toharudin. (2011). Membangun Literasi Sains siswa. Bandung: Humaniora.

[2] Utami, D, D. (2018). "Upaya Peningkatan Literasi Sains Siswa Dalam Pembelajaran IPA". Prosiding Seminar Nasional MIPA IV, 1(1), 133-137.

[3] Fathuroman, A., Zulherma, dan F. Kurnia. (2014). Analisis Bahan Ajar Fisika SMA Kelas IX di Kecamatan Indralayu Utara Berdasarkan Kategori Literasi Sains. Jurnal Inovasi dan Pembelajaran Fisika, 1 (1), 4347.

[4] Taufiq, M., Amalia, A. V., Parmin, P., dan Leviana, A. (2016). Design of Science Mobile Learning of Eclipse Phenomena with Conservation Insight Android-Based App Inventor 2. Jurnal Pendidikan IPA Indonesia, 5(2), 291-298.

[5] Putri, A., Suciati, dan Ramli. (2014). Pengaruh Model Problem Based Learning Berbasis Potensi Lokal Pada Pembelajaran Biologi Terhadap Kemampuan Literasi Sains Siswa Kelas X SMA Negeri 1 Cepg. Jurnal Pendidikan Biologi FKIP UNS, 3(2), 81-94.

[6] Giriyanti, P., R. Ading, P., dan Milla, L. (2017). Pengaruh Model Pembelajaran Berbasis Masalah Terhadap Kemampuan Literasi Sains Siswa Pada Materi Ekositem Kelas X SMA. Jurnal Skripsi Pendidikan Biologi, 1-8.

[7] Suyanti, R. D. (2010). Strategi Pembelajaran Kimia. Yogyakarta: Graha Ilmu.

[8] Astuti, N. (2018). Pembelajaran Larutan Elektrolit dan Non Elektrolit Dengan Multimedia Adobe Flash CS6 Melalui Model Inkuiri Terbimbing dan Discovery Learning di Kelas X MIPA SMAN Titian Teras.

[9] Fatimah, F. (2012). Kemampuan Komunikasi Matematis dan Pemecahan Masalah Melalui Problem Based Learning. Jurnal Penelitian dan Evaluasi Pendidikan, 16 (1), 249-260.

[10] Sugiyono. (2019). Statistika Untuk Penelitian. Bandung: Alfabeta.

[11] Sugiyono. (2014). Metode Penelitian Kuantitatif, Kualitatif dan $R \& D$. Bandung: Alfabeta.

[12] Burhan. (2014). Penelitian Kualitatif. Jakarta: Kencana Prenada Media.
[13] Haerani, S. A. S., Setiadi, D., \& Rasmi, D. A. C. (2020). Pengaruh Model Inkuiri Bebas Terhadap Kemampuan Literasi Sains. J. Pijar MIPA, 15(2), 140-144.

[14]Fauziah, N., Hakim, A., \& Andayani, Y. (2019). Meningkatkan literasi sains peserta didik melalui pembelajaran berbasis masalah berorientasi green chemistry pada materi laju reaksi. Jurnal Pijar MIPA, 14(2), 31-35. 